\title{
GENERIC DIVERSITY IN PHASE OF RHYTHM IN FORMICINE ANTS
}

\author{
By E. S. McCluskey \\ Departments of Physiology and of Biology \\ Loma Linda University, Loma Linda, California 92354
}

Ants are abroad through most of the day and night. But the species composition of this 24-hour patrol changes from one part of the day to the next (Talbot 1953; Wilson I97I). For example, in Michigan the maximum foraging activity of Lasius neoniger is at night, of Myrmica americana in the early morning and late afternoon, and of Formica pallidefulva nitidiventris in the middle of the day (Talbot 1946, I953).

Likewise the mating flights of ants occur at different hours for different species (Kannowski 1963; Talbot 1945). The flight times may be similar for closely-related species (Kannowski 1959a).

If one were to look at many species of one genus, would he find them to be similar as to time of day of foraging or of mating flight? Or does each genus span the 24 hours in terms of its various species? The aim of this report is to quantitatively compare species diversity with generic diversity of such phase relationships in one tribe of ants, the Formicini. The biosystematics of much of this group, particularly of the genera Lasius, Acanthomyops, and Formica, is relatively well known on morphological and zoogeographic grounds (Wilson and Regnier 1971).

The comparisons are based on a compilation of literature records for as many species and genera as possible in this tribe (Figs. I and 2). A genus was included if there were records for three or more species. About a third of the species of Acanthomyops, of Cataglyphis, of Lasius, and of Myrmecocystus are represented in the records cited here, but a smaller fraction of the large genus Formica. These genera are all from North Temperate latitudes. (For a preliminary report see McCluskey, 1972.)

The workers could be classified as nocturnal, diurnal, etc. But in the absence of single or definite beginning points or midpoints of activity in most of the literature records, another method was used to reduce each rhythm to one point for comparison with other species: If the ants do not normally come above ground at all (e.g., Acanthomyops species), the species is plotted as an $X$ at the extreme left (Fig. I) ; if nocturnal only, one position farther to the right; if out 
as late as sunrise, another position to the right; etc. As far as possible, only summer records were used so as to make directly comparable.

It can be seen that the species in Acanthomyops, in Formica, and in Cataglyphis are closely grouped within each genus. The species in Lasius appear less so, but they barely overlap those of Formica or Cataglyphis.
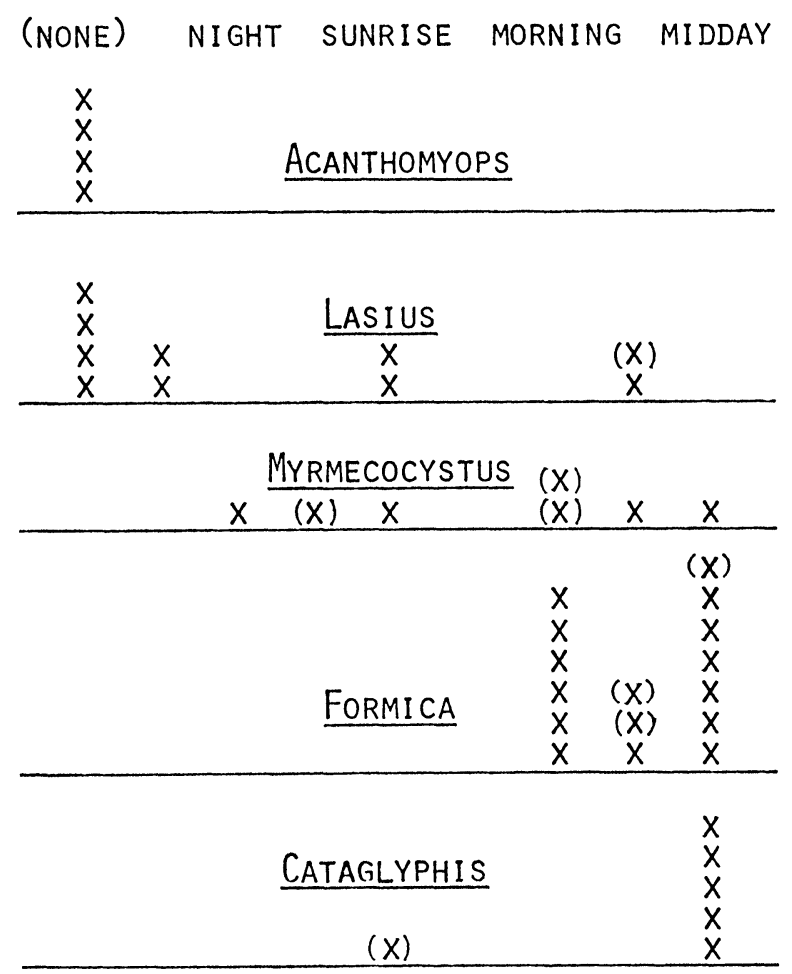

Figure I 
Scoring an $X$ in the leftmost column of Fig. I as "I", next to the left ("night") as " 2 ", and finally the rightmost column as " 5 ", permits an analysis-of-variance comparison of the variation within a genus with the variation between the genera:

$\begin{array}{llllll} & \mathrm{SS} & \mathrm{df} & \mathrm{ms} & \mathrm{F} & \mathrm{P}< \\ \text { among genera } & 66 . \mathrm{I} & 4 & \mathrm{I} 6.5 & \mathrm{I} 6.5 & . \text {.O I } \\ \text { within genera } & 36.9 & 37 & \text { I.O } & & \end{array}$

Thus the likeness within genera is greater than that between genera.

A different type of analysis confirms this conclusion. The "none" aboveground activity was now omitted, since that is not really a time character (thus eliminating Acanthomyops and some Lasius species); the "night" species were arbitrarily considered as (out until) 5 AM, "sunrise" 7 AM, "morning" Io AM and "midday" I PM. These hours were treated as angles of a circular distribution, and the mean angles of the different samples (genera) were compared by Watson

Fig. 1. Worker surface activity (limited mainly to summer records, for most direct comparison of species). Each $X$ represents one species and shows its nearest approach to midday; those based on the most limited cited records are enclosed in (). The leftmost column "NONE" indicates that the species does not usually come above ground at all. Following are species and literature sources represented: FORMICA: bradleyi (Wheeler and Wheeler 1963), dakotensis (Talbot 1971), exsectoides (Andrews 1927, 1929; McCook 1877), fusca (Morisita 1939), fusca lemani (Brian 1955), lasioides (Wheeler and Wheeler 1970), neogagates (Talbot 1953), obscuripes (Weber 1935), pallidefulva nitidiventris (Talbot 1946, 1953, 1965), polyctena (Bruns 1954; Chauvin 1965a,b), pratensis (Stebaev 1971; Stebaev and Reznikova 1972), sibylla (Wheeler 1917), subintegra (Talbot and Kennedy 1940), subnitens (Ayre 1958, 1959), subpilosa (Stebaev 1971; Stebaev and Reznikova 1972), subpolita (Mallis 1941), ulkei (Holmquist 1928). LASIUS: emarginatus (Tohmé 1969), flavus (Bernard 1968; Odum and Pontin 1961; Talbot 1965; Wilson 1955), fuliginosus (Wilson 1955), minutus (Kannowski 1959b; Talbot 1965), neoniger (Talbot 1946, 1953, 1965), niger (Eidmann 1926; Morisita 1939), sitiens (Wilson 1955), sitkaensis (now pallitarsis) (Talbot 1965; Wilson 1955), speculiventris (Talbot 1965), umbratus (Stärcke 1937; Talbot 1965; Wilson 1955). ACANTHOMYOPS: claviger, interjectus, latipes, and murphyi (Talbot 1963; Wheeler and Wheeler 1963). MYRMECOCYSTUS: lugubris (Cole 1966), melliger orbiceps (now placodops) (Wheeler 1908b), mexicanus (Cole 1966; LaRivers 1968), mexicanus hortideorum (McCook 1882), mimicus (Cazier and Statham 1962; Leonard 1911), mojave (Cole 1966; LaRivers 1968; Leonard 1911), pyramicus (Smith 1951), wheeleri (Snelling 1971). CATAGLYPHIS: albicans (Délye 1968), albicans viaticoides (Tohmé 1969), altisquamis (Tohmé 1969), bicolor (Délye 1968; Pickles 1944; Tohmé 1969; Wehner and Duelli 1971), bicolor setipes (Gupta 1970), bombycina (Délye 1968), frigida (Tohmé 1969), lucasi (Baroni Urbani 1969; Délye 1964). An annotated table giving the details of support for Figs. 1 and 2 is available from the author. 


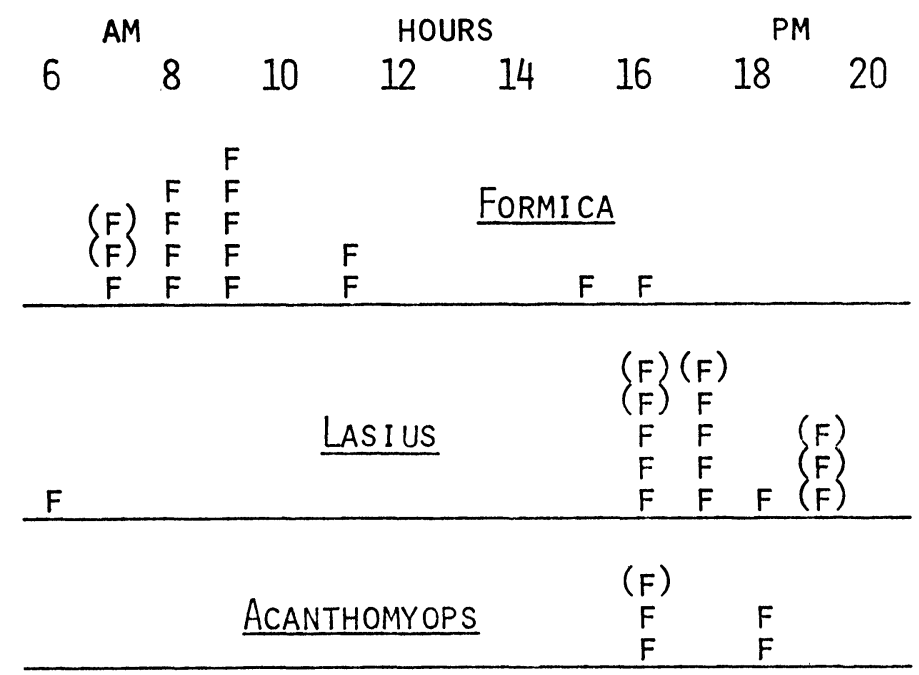

Fig. 2. Flight hours. Each $F$ represents for one species the halfway point between the earliest and latest literature records of flight; () indicate the most fragmentary records. The following are represented: FORMICA: dakotensis (Talbot 1971), fusca (Kannowski 1959a; Talbot 1965), montana (Kannowski 1963; Kannowski and Johnson 1969), neogagates (Talbot 1966), obscuripes (Clark and Comanor 1972; Talbot 1971), obscuriventris (Talbot 1964), opaciventris (Scherba 1961), pallidefulva nitidiventris (Talbot 1948), pergandei (Kannowski and Johnson 1969), pratensis (Eidmann 1928; Wheeler 1908a), rufa (Donisthorpe 1927; Standen 1909), rufibarbis (Forel 1874a), sanguinea (Forel 1874b), subintegra (Kannowski 1963; Talbot and Kennedy 1940), subnitens (Ayre 1957), ulkei (Scherba 1958; Talbot 1959). LASIUS: alienus (Gösswald 1932; Hall 1887), brunneus (Forel 1874b; Schenck 1852), carniolicus (Kutter 1946), emarginatus (Forel 1874b, 1928), flavus (Donisthorpe 1927; Forel 1874b; Talbot 1965; Wilson 1955), fuliginosus (Wilson 1955), minutus (Kannowski 1959a; Talbot 1965), nearcticus (Wilson 1955), neoniger (Kannowski 1963; Talbot 1945, 1965; Wilson and Hunt 1966), nevadensis (Cole 1956), niger (Donisthorpe 1927; Forel 1874b), pallitarsis (Medler 1958; Talbot 1965), speculiventris (Kannowski 1959a; Talbot 1965), subumbratus (Kannowski 1971), umbratus (Crawley 1913; Forel 1874a, 1875; Kannowski 1963; Rau 1934)*. ACANTHOMYOPS: claviger (Talbot 1963, 1973), interjectus (Talbot 1963), latipes (Gregg 1963; Talbot 1963, 1973), murphyi (Talbot 1963), subglaber (Talbot 1973).

*The morning record (Rau 1934) is most unusual for this species (Kannowski 1963) and I omitted it in plotting the midpoint in the graph. Crawley (1913) and Forel (1874a, 1875) may possibly refer to a sibling species of umbratus (cf. Wilson 1955). 
and Williams' (1956; cf. Batschelet I965, but only for a twosample case) test: if the samples are considered random, $\mathrm{F}_{\mathrm{q}-1, \mathrm{~N}-\mathrm{q}}=$ $[(\mathrm{N}-\mathrm{q})(\Sigma \mathrm{R}-\mathrm{R})] /\left[(\mathrm{q}-\mathrm{I})\left(\mathrm{N}-\Sigma \mathrm{R}_{\mathrm{i}}\right)\right]=3.58$ and $\mathrm{P}<.05$ $\left[N=33\right.$ (species), $q=4$ (genera), $R_{i}$ refers to the combination vector for all the species in each genus, and $R$ refers to the combination vector of all genera].

Figure 2 shows that for the three genera of this tribe with enough species records, the flight hours of the species within a genus are strikingly similar, exceptions being the one morning species of Lasius and the two afternoon species of Formica. Comparison of the flight hours by the Watson and Williams test again shows the likeness within genera to be greater than that between genera $(\mathrm{P}<$.OOI $)$.

It seems noteworthy that a single rhythm character would characterize a genus this well. A preliminary test for generality of the within-genus likeness of flight hour was made on eleven genera from five subfamilies of ants (all of those from which literature records of at least three species per genus were at hand). The Watson and Williams test gives a value of $\mathrm{P}<.00 \mathrm{I}$; this is true also if the three formicine genera are omitted and only the other eight considered.

By including all species records no matter what tribe, it is possible in a few cases to rank workers from early to late within each given locality (McCluskey, unpublished). Again species appear grouped generically, giving further suggestive evidence of a taxonomic or historical explanation of the phase differences (as opposed to a strictly ecological or geographical explanation).

An example of a physiological character earlier shown to correlate well with a previously-established classification is that by Priesner ( I968). Male moths throughout the family Saturniidae were shown to react to pheromone from the females in a manner roughly corresponding to taxonomic grouping.

It should be added that some of the phase relationships considered here might in fact be explained by response to temperature, since these are records from the field rather than a constant temperature laboratory. But this consideration does not change the fundamental nature of the conclusion drawn. Further, certain ants which have been studied in constant temperature exhibit a phase relationship to the light cycle similar to that in the field (McCluskey 1963, I965, r969; McCluskey and Carter r969).

\section{SUMMARY}

Literature records of field mating flight and worker rhythms indicate the phase to be much more alike from species to species within 
a genus than between genera. The analysis is based on about a third of the world species in each of several genera of the tribe Formicini. Comparison in more genera, from several subfamilies, again indicates this prominent within-genus likeness of behavior.

\section{AcKNowledgements}

I thank P. Y. Yahiku for help with statistics, and L. R. Brand, D. G. Kissinger, and R. E. Ryckman for reading the manuscript.

\section{Literature Cited}

Andrews, E. A.

1927. Ant-mounds as to temperature and sunshine. J. Morphol. 44:1-20.

1929. The mound-building ant, Formica exsectoides F., associated with Ayre, G. L. tree-hoppers. Ann. Entomol. Soc. Amer. 22: 369-391.

1957. Ecological notes on Formica subnitens Creighton (Hymenoptera: Formicidae). Insectes Soc. 4: 173-176.

1958. Some meteorological factors affecting the foraging of Formica subnitens (Hymenoptera: Formicidae). Insectes Soc. 5: 147-157.

1959. Food habits of Formica subnitens Creighton (Hymenoptera: Formicidae) at Westbank, British Columbia. Insectes Soc. 6: 105-114.

Baroni URBani, C.

1969. Una nuova Cataglyphis dei monti dell'Anatolia. Fragmenta Entomologica $6: 213-222$.

BATSChelet, E.

1965. Statistical methods for the analysis of problems in animal orientation and certain biological rhythms. American Institute of

Bernard, F. Biological Sciences, Washington, D.C. 57 p.

1968. Les fourmis (Hymenoptera Formicidae) d'Europe occidentale et septentrionale, 360. Masson et Cie, Paris.

BRIAN, M. V.

1955. Food collection by a Scottish ant community. J. Anim. Ecol. 24 : 336-351.

BRUNS, H.

1954. Z. Tierpsychol. 11: 151-154 (cited by Sudd 1967).

Cazier, M. A., and M. Statham.

1962. The behavior and habits of the myrmecophilous scarab Cremastocheilus stathamae Cazier with notes on other species (Coleoptera: Scarabaeidae). J. N. Y. Entomol. Soc. 70: 125-149.

Chauvin, R.

1965a. Enregistrement de l'activité dans les conditions naturelles sur les pistes de Formica polyctena. Insectes Soc. 12: 131-144.

1965b. L'activité sur les pistes et les fourmilières de Formica polyctena, p. 47-53. In R. Chauvin [ed.], La distribution temporelle des activités animales et humaines, Masson et Cie, Paris.

Clark, W. H., and P. L. Comanor.

1972. Flights of the western thatching ant, Formica obscuripes Forel, in Nevada (Hymenoptera: Formicidae). Great Basin Naturalist 32: 202-207. 
Col.E, A. C.

1956. Studies of Nevada ants. II. A new species of Lasius (Chthonolasius) (Hymenoptera: Formicidae). J. Tennessee Academy Science 31:26-27.

1966. Ants of the Nevada Test Site. Brigham Young University Science Bull., Biological Series 7 (3): 1-27.

Crawley, W. C.

1913. Further experiments on the temporary social parasitism in ants of the genus Lasius, Fab., with a note on Antennophorus uhlmanni. Entomologist's Record Journal Variation 25: 135-138.

DÉLYY, G.

1964. Sur le peuplement myrmécologique de quelques ergs du Sahara nord-occidental. Travaux Institut Recherches Sahariennes Univ. Alger 23 : 165-169.

1968. Recherches sur l'écologie, la physiologie et l'éthologie des fourmis du Sahara. Thesis, Marseille. $155 \mathrm{p}$.

DONISTHORPE, H.

1927. British ants, their life-history and classification, 2nd ed. Routledge, London. $436 \mathrm{p}$.

EIDMAN N, H.

1926. Die koloniegründing der einheimischen ameisen. Z. Vergl. Physiol. 3: 776-826 (cited by Wilson 1955).

1928. Weitere beobachtungen uber die koloniegrundung einheimischer ameisen. Z Vergl. Physiol. 7: 39-55 (cited by Kannowski 1963).

Forel, A.

1874a. Denkschr. Schweiz. Ges. Naturw. 26: 407-408 (cited by Donisthorpe 1927).

1874b. Les fourmis de la Suisse. Nouv. Mem. Soc. Helv. Sc. Nat. Zurich 26: 447 p. (cited by Kannowski 1963).

1875. Bull. Soc. Vaudoise Sci. Natur. 14: 69 (cited by Donisthorpe 1927).

1928. The social world of the ants, vol. 1, p. 416. Putnam's, New York. GössWALD, K.

1932. Ökologische studien über die ameisenfauna des mittleren maingebietes. Z. Wiss. Zool. 142: 1-156.

GREGG, R. E.

1963. The ants of Colorado, p. 488. University of Colorado, Boulder.

Gupta, C. S.

1970. Ecological studies on the ant Myrmecocystus setipes Forel. Gurukul Kangri Vishwavidyalaya Journal Scientific Research 2: 134-148.

HALL, C. G.

1887. Swarms of Lasius niger, L., var. alienus, Först., near Dover. Entomologist's Monthly Magazine 24: 91.

Holmquist, A. M.

1928. Notes on the life history and habits of the mound-building ant, Formica ulkei Emery. Ecology 9: 70-87.

KAN NOWSKI, P. B.

1959a. The flight activities and colony-founding behavior of bog ants in southeastern Michigan. Insectes Soc. 6: 115-162.

$1959 \mathrm{~b}$. The use of radioactive phosphorus in the study of colony distribution of the ant Lasius minutus. Ecology 40:162-165. 
1963. The flight activities of formicine ants Symp. Genet. Biol. Ital. 12: 74-102.

1971. Unusual occurrence of winged ants in beach drift. Prairie Naturalist $3: 61-64$.

Kan Nowski, P. B., AND R. L. Johnson.

1969. Male patrolling behavior and sex attraction in ants of the genus Formica. Anim. Behav. 17: 425-429.

KUTTER, $\mathrm{H}$.

1946. Lasius (Chthonolasius) carniolicus Mayr, eine neue Schweizerameise. Mitt. Schweiz. Entomol. Ges. 19: 698-699 (cited by Wilson 1955).

LARIVERS, I.

1968. A first listing of the ants of Nevada (Hymenoptera: Formicidae). Biological Society Nevada Occasional Papers 17: 1-12.

LEONARD, $P$.

1911. The honey ants of Point Loma, California. Trans. San Diego Society Natural History $1(3)$ : 85-97.

Mallis, A.

1941. A list of the ants of California with notes on their habits and distribution. Southern California Acad. Sci. Bull. 40: 61-100.

McCluskey, E. S.

1963. Rhythms and clocks in harvester and Argentine ants. Physiol. Zool. 36: 273-92.

1965. Circadian rhythms in male ants of five diverse species. Science 150 : 1037-1039.

1969. Field and laboratory timing of the flights of a harvester ant. American Zoologist 9:566 (abstract).

1972. Rhythm characters distinguish certain genera of ants. American Zoologist 12(3): xxviii (abstract).

McCluskey, E. S., and C. E. Carter.

1969. Loss of rhythmic activity in female ants caused by mating. Comp. Biochem. Physiol. 31 : 217-226.

McCook, H. C.

1877. Mound-making ants of the Alleghenies, their architecture and habits. Trans. Amer. Entomol. Soc. 6: 253-296.

1882. The honey ants of the Garden of the Gods, and the occident ants of the American plains, p. 29-30. Lippincott, Philadelphia.

MedLer, J. T.

1958. A note on swarming and emergence of ants (Hymenoptera: Formicidae). Proc. Entomol. Soc. Wash. 60: 258.

Morisita, M.

1939. On the daily rhythm of activity of ants. II, Activity of Lasius niger L. Ecol. Rev. (Sendai) 5: 179-184 (Japanese, with English summary).

Odum, E. P., AND A. J. Pontin.

1961. Population density of the underground ant, Lasius flavus, as determined by tagging with $P^{32}$. Ecology 42: 186-188.

Pickles, W.

1944. The territory and activities of the Algerian ant Cataglyphus bicolor F. s-sp. megalocola Först. Entomologist's Monthly Magazine $80: 61-63$. 
Priesner, E.

1968. Die interspezifischen wirkungen der sexuallockstoffe der Saturniidae (Lepidoptera). Z. Vergl. Physiol. 61: 263-297.

RAU, P.

1934. Notes on the behavior of certain ants of St. Louis Co., Mo. Trans. Acad. Sci. St. Louis $28: 207-215$.

SCHENCK, A.

1852. Beschreibung nassauischer ameisenarten. Jahrb. Ver. Naturk. Nassau 8 (1) : 3-149 (cited by Kannowski 1963).

Scherba, G. M.

1958. Reproduction, nest orientation and population structure of an aggregation of mound nests of Formica ulkei Emery (Formicidae). Insectes Soc. 5: 201-213.

1961. Nest structure and reproduction in the mound-building ant Formica opaciventris Emery in Wyoming. J. N. Y. Entomol. Soc. 69: 71-78.

SMITH, M. R.

1951. Two new ants from western Nevada (Hymenoptera: Formicidae). Great Basin Naturalist 11: 91-96.

SNELLING, R. R.

1971. Studies on California ants. 6. Three new species of Myrmecocystus (Hymenoptera: Formicidae). Los Angeles County Museum Contributions Science 214: 1-16.

STANDEN, $R$.

1909. Gull and ants. Lancashire Nat. 2: 190 (cited by Kannowski 1963).

STÄRCKE, A.

1937. Retouches sur quelques fourmis d'Europe. II. Lasius groupe umbratus Nylander. Tijdschr. Ent. 80: 38-72 (cited by Wilson 1955).

StebaeV, I. V.

1971. Structure of the protected territory of Formica pratensis and interaction of ants from the same and different species. Zool. Zh. 50: 1504-1519 (Russian, with English summary).

StebaeV, I. V., AND J. I. Reznikova.

1972. Two interaction types of ants living in steppe ecosystem in South Siberia, USSR. Ekologia Polska 20: 103-109.

SudD, J. H.

1967. An introduction to the behaviour of ants. Arnold, London. 200 p.

Talbot, M.

1945. A comparison of flights of four species of ants. Amer. Midland Naturalist 34: 504-510.

1946. Daily fluctuations in aboveground activity of three species of ants. Ecology 27: 65-70.

1948. A comparison of two ants of the genus Formica. Ecology 29: 316-325.

1953. Ants of an old-field community on the Edwin S. George Reserve, Livingston County, Michigan. Contributions Laboratory Vetebrate Biology University of Michigan $63: 1-13$. 
1959. Flight activities of two species of ants of the genus Formica. Amer. Midland Naturalist $61: 124-132$.

1963. Local distribution and flight activities of four species of ants of the genus Acanthomyops Mayr. Ecology 44: 549-557.

1964. Nest structure and flights of the ant Formica obscuriventris Mayr. Anim. Behav. 12:154-158.

1965. Populations of ants in a low field. Insectes Soc. 12:19-48.

1966. Flights of the ant Aphaenogaster treatae. J. Kans. Entomol. Soc. 39: 67-77.

1971. Flights of the ant Formica dakotensis Emery. Psyche 78: 169-179.

1973. Five species of the ant genus Acanthomyops (Hymenoptera: Formicidae) at the Edwin S. George Reserve in southern Michigan. Great Lakes Entomologist 6: 19-22.

TALBot, M., AND C. H. KenNEDY.

1940. The slave-making ant, Formica sanguinea subintegra Emery, its raids, nuptual flights and nest structure. Ann. Entomol. Soc. Amer. 33 : 560-577.

Тонме́, G.

1969. Répartition géographique des fourmis du Liban (Hymenoptera: Formicoidea). Thesis, Toulouse. $77 \mathrm{p}$.

Watson, G. S., and E. J. Williams.

1956. On the construction of significance tests on the circle and the sphere. Biometrika $43: 344-352$.

WEBER, N. A.

1935. The biology of the thatching ant, Formica rufa obscuripes Forel, in North Dakota. Ecol. Monogr. 5: 165-206.

Wehner, R., ANd P. Duelli.

1971. The spatial orientation of desert ants, Cataglyphis bicolor before sunrise and after sunset. Experientia 27: 1364-1366.

WheEler, G. C., AND J. WheELer.

1963. The ants of North Dakota. University of North Dakota, Grand Forks. 207 p.

1970. The natural history of Manica (Hymenoptera: Formicidae). J. Kans. Entomol. Soc. $43: 129-162$.

WhEELER, W. M.

1908a. Comparative ethology of the European and North American ants. J. Psychol. Neurol. 13 : 404-435 (cited by Kannowski 1963).

1908b. Honey ants, with a revision of the American Myrmecocysti. Bull. Amer. Mus. Natur. Hist. 25 : 345-397.

1917. The mountain ants of western North America. Amer. Acad. Arts Sci., Proc. 52: 457-569.

WILSON, E. O.

1955. A monographic revision of the ant genus Lasius. Mus. Comp. Zool. Bull. 113 : 1-201.

1971. The insect societies, p. 214. Harvard University, Cambridge.

Wilson, E. O., and G. L. Hunt.

1966. Habitat selection by queens of two field-dwelling species of ants. Ecology 47: 485-487.

Wilson, E. O., AND F. E. Regnier, JR.

1971. The evolution of the alarm-defense system in the formicine ants. Amer. Natur. 105 : 279-289. 

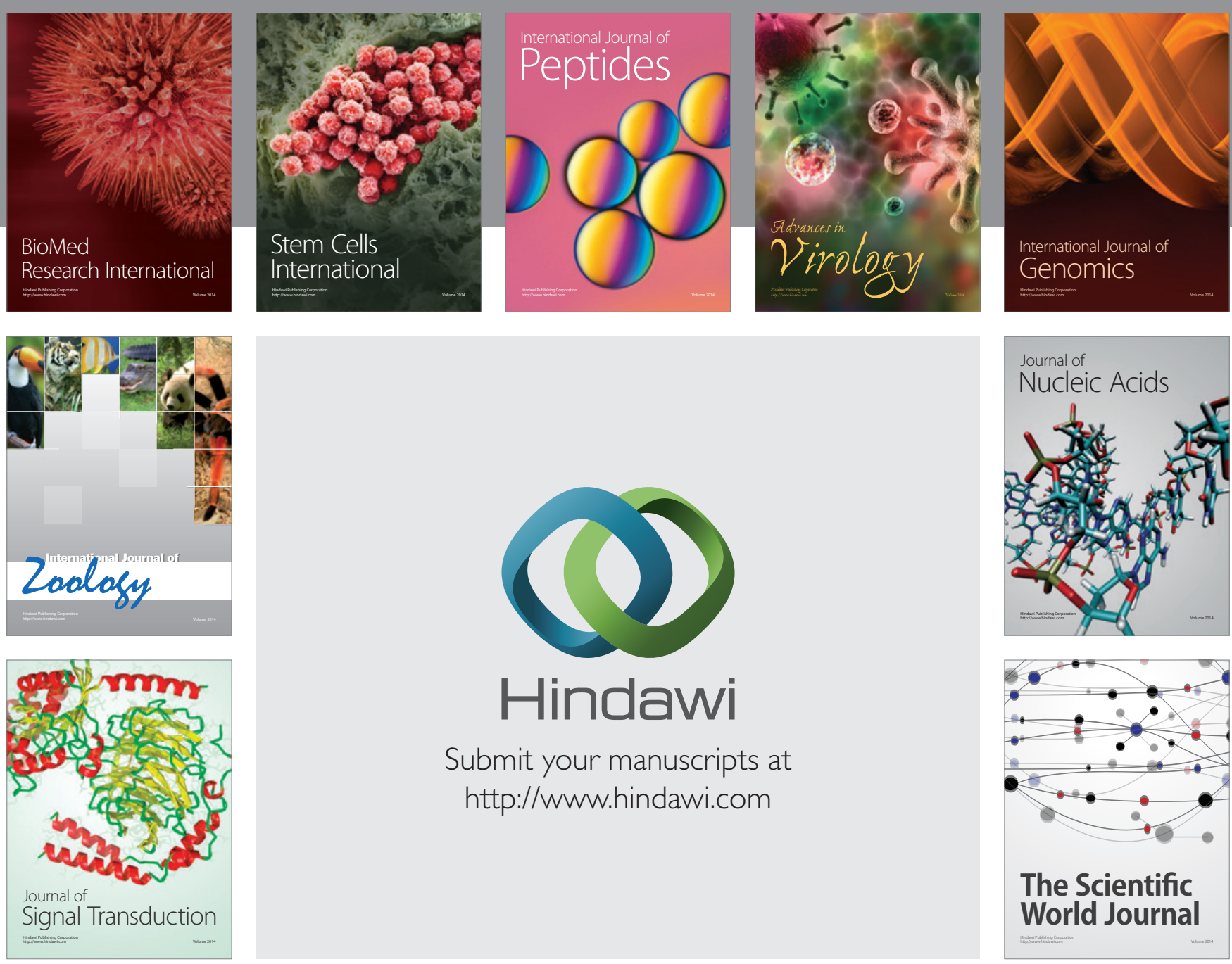

Submit your manuscripts at

http://www.hindawi.com
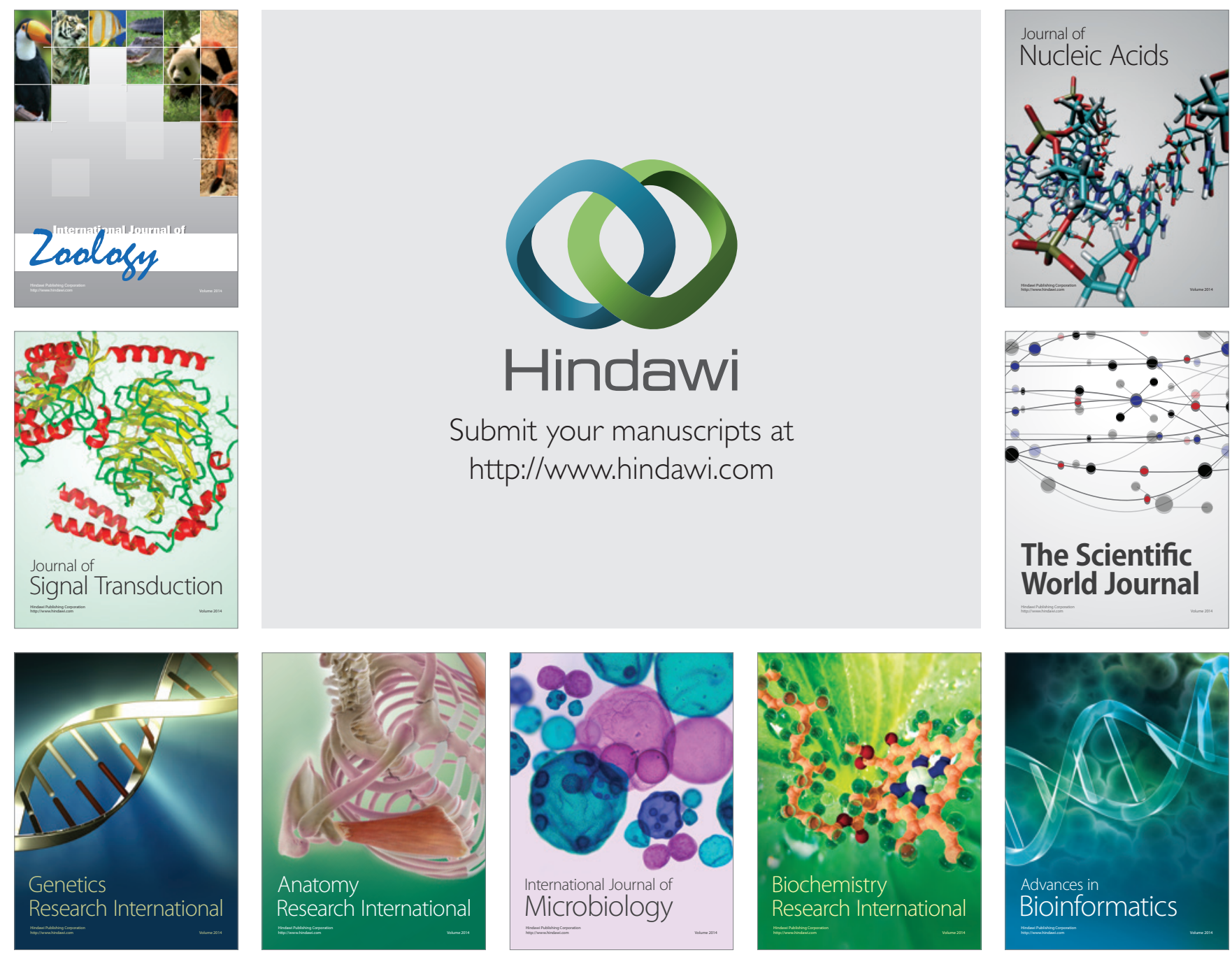

The Scientific World Journal
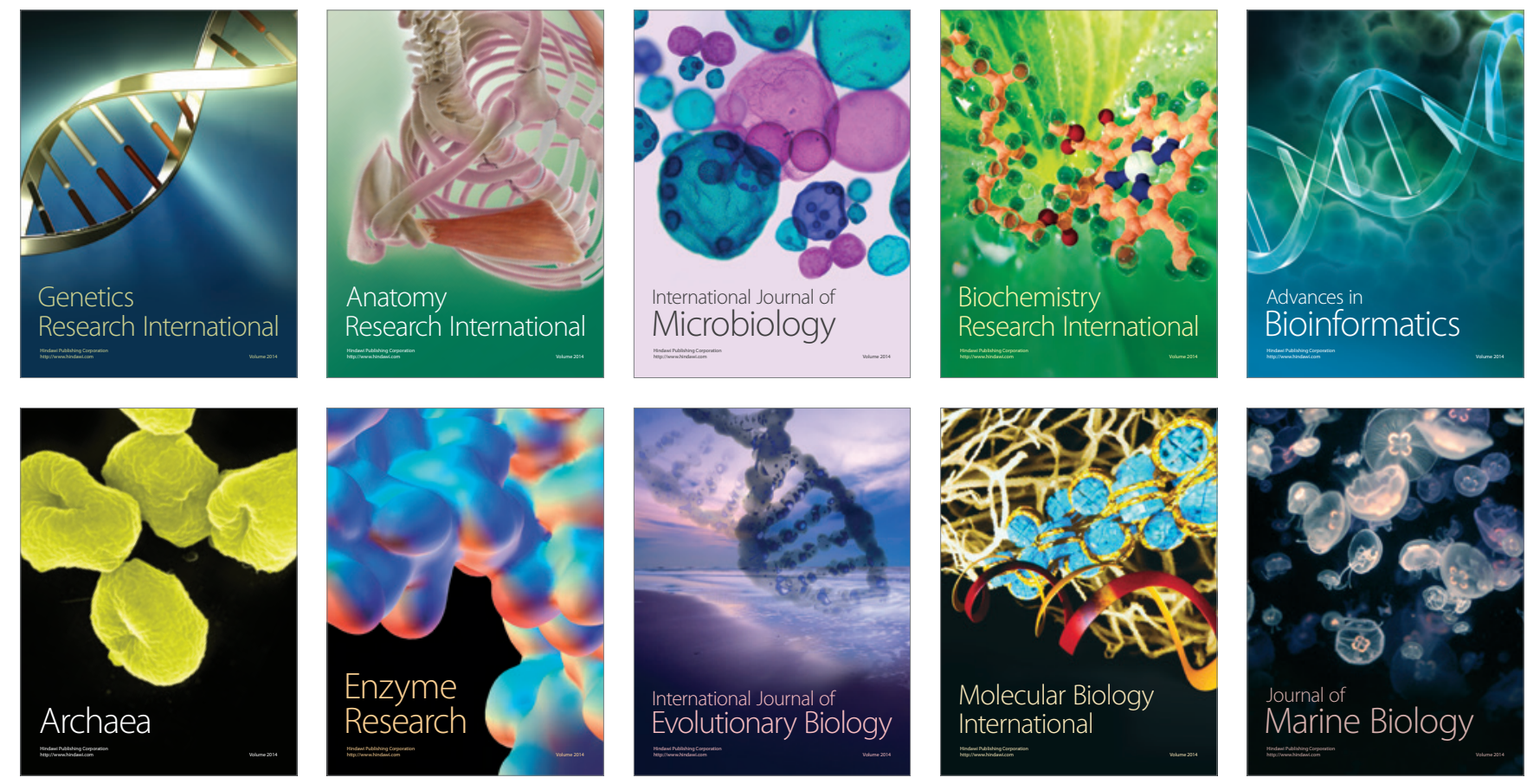